\title{
Prey abundance and prey selection by tigers (Panthera tigris) in a semi-arid, dry deciduous forest in western India
}

\author{
S. Bagchi, S. P. Goyal* and K. Sankar \\ Wildlife Institute of India, P.O. Box No. 18, Dehradun-248001, Uttaranchal, India \\ (Accepted 19 December 2002)
}

\begin{abstract}
Food habits of tigers Panthera tigris in terms of prey abundance were studied in the semi-arid deciduous forests of Ranthambhore National Park, western India, between November 2000 and April 2001. Wild prey availability was assessed by line transects $(n=8)$ and prey selection by the tigers was determined from analysis of scats $(n=$ 109). Compared to some other parts of the country, prey abundance was found to be high at 96.65 animals km$~^{-2}$. Chital Axis axis was the most abundant wild prey in the study area, followed by common langur Presbytis entellus, sambar Cervus unicolor, nilgai Boselaphus tragocamelus, wild pig Sus scrofa and chinkara Gazella bennetti. Chital (c. 31\%) and sambar (c. 47\%) constituted the bulk of the tigers' diet and were preferred prey. Nilgai and chinkara contributed minimally to the tigers' diet (c. 5-7\% and $<1 \%$, respectively) and were used less than their availability. Domestic livestock made up 10-12\% of the tigers' diet. The average weight of an animal consumed was between 107 and $114 \mathrm{~kg}$ reflecting a preference for large prey. The analysis reveals that parts of Ranthambhore have high prey abundance, thus making it important for long-term tiger conservation. Despite the high prey abundance, tigers were still considerably dependent on domestic livestock, posing challenges for the park management to resolve potential areas of conflict.
\end{abstract}

Key words: food habits, line transect, Panthera tigris, tiger, prey selection, scat analysis

\section{INTRODUCTION}

Increasingly, it is being realized that the decline of large carnivores is a global conservation concern (Weber \& Rabinowitz, 1996). Effective conservation of large predators requires the assessment of a complex mix of ecological, ethical and symbolic inter-relationships (Kellert et al., 1996). The tiger Panthera tigris L. is revered as a cultural icon over much of its range and yet it has been continually threatened by hunting, habitat loss, fragmentation of populations and most importantly, the depletion of its prey base (Karanth \& Stith, 1999). It is alarming that three subspecies of tiger have already become extinct in the wild (Sunquist, Karanth \& Sunquist, 1999). Factors affecting prey choice in tigers differ across its distributional range, and need to be understood as it occupies diverse habitats (Sunquist \& Sunquist, 1989). Such an understanding would reflect the ability of tigers to adapt to landscapes modified by humans, and prove important for effective conservation planning. Thus, studying the food habits of tigers in relation to their prey base is essential for better management of their habitats, especially for the last remnant populations in semi-arid

*All correspondence to: S. P. Goyal. E-mail: goyalsp@wii.gov.in and dry deciduous parts of western India. The food habits of tigers were examined and prey selection assessed in a semi-arid, dry-deciduous forest of western India in relation to pertinent conservation issues of this region.

\section{STUDY AREA}

The study was carried out between November 2000 and April 2001 in an intensive study area (ISA) of $34 \mathrm{~km}^{2}$ in Ranthambhore National Park $\left(392 \mathrm{~km}^{2}\right)$, which is the core zone of Ranthambhore Tiger Reserve $\left(1334 \mathrm{~km}^{2}\right.$; $26^{\circ} \mathrm{N}, 76^{\circ} \mathrm{E}$; Fig. 1). There are 332 villages within a $5 \mathrm{~km}$ radius of the reserve, four of which are inside the core area. Consequently, human pressures are high, with $>143000$ head of livestock dependent on it. The livestock population has been increasing in the region by $2 \%$ annually (Jain, 2001). The park-people interface is being addressed by the eco-development projects initiated in the tiger reserve (World Bank, 1996; MacKinnon, Mishra \& Mott, 1999; Jain, 2001). The vegetation of this region is tropical dry deciduous forest and tropical thorn forest (Champion \& Seth, 1968). Anogeissus pendula Edgew, Acacia leucophloea (Roxb.) Willd. and Butea monosperma (Lamk.) Taub. are the dominant trees, Grewia flavescens Juss. and Capparis sepiaria L. are 


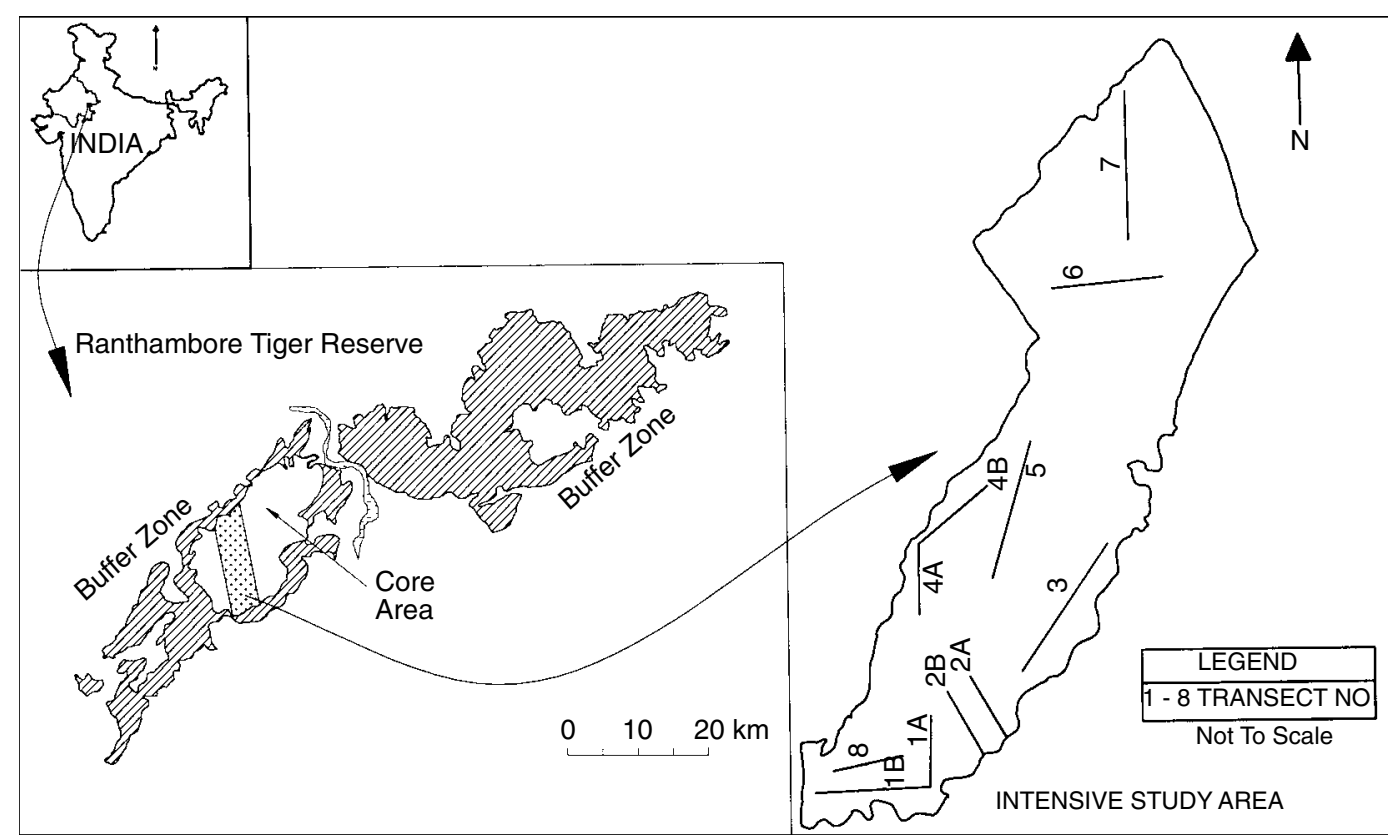

Fig. 1. Location of intensive study area (ISA) in Ranthambhore Tiger Reserve where eight line transects were laid for estimating animal densities during November 2000 to April 2001.

the common shrubs (Sharma, 1983). The terrain is hilly, undulating with wide valleys and plateaux. The climate is dry tropical having four distinct seasons: summer (March-June), followed by monsoon (July-August), postmonsoon (September-October) and winter (NovemberFebruary). The average annual rainflall of c. $800 \mathrm{~mm}$ occurs mostly during July-September.

Apart from tigers, other large carnivores present are leopards Panthera pardus L. and striped hyenas Hyaena hyaena $\mathrm{L}$. The potential mammalian prey species are chital Axis axis Erxleben, sambar Cervus unicolor Kerr, nilgai Boselaphus tragocamelus Pallas, chinkara Gazella bennetti Sykes, wild pig Sus scrofa L., common langur Presbytis entellus Dufresne, porcupine Hystrix indica Kerr and hare Lepus nigricollis ruficaudatus F. Cuvier. Domestic livestock (chiefly cattle and buffalo) are also potential prey items.

\section{METHODS}

\section{Estimating the density of wild prey species}

Distance sampling by line transects (Burnham, Anderson \& Laake, 1980; Buckland et al., 1993) was used to estimate densities of chital, sambar, nilgai, chinkara, wild pig and common langur in the ISA. This method is efficient (Anderson et al., 2001) and has been widely applied in tropical forests (Karanth \& Sunquist, 1992; Varman \& Sukumar, 1995; Khan et al., 1996; Biswas \& Sankar, 2002) as it provides relatively unbiased results if certain assumptions are met (Buckland et al., 1993). Eight line transects (ranging from 1.5 to $2.8 \mathrm{~km}$ ) were laid in a stratified random manner according to broad topographic classes like slopes, valleys and plateaux (Fig. 1), totalling $19.5 \mathrm{~km}$. Location and length of transects were constrained by logistic support like accessibility on foot. Each transect was walked 14 times during morning and evening hours when animals were most active, resulting in $273 \mathrm{~km}$ of walk. On every animal sighting, the following data were recorded:

(1) Species and group size: one or more animals of the same species within $30 \mathrm{~m}$ of each other and showing signs of coordinated movements were considered as a group;

(2) Sighting angle: sighting angle to the centre of the group was calculated using a hand-held compass (KB 20, Suunto, Vantaa, Finland);

(3) Sighting distance: the distance to the centre of group from the point of observation was measured using a range finder (Yardage Pro 400, Bushnell, Overland Park, Kansas, USA).

The program Distance (version 3.5; Laake et al., 1998) was used to estimate animal densities. Minimum Akaike information criterion was used to judge the models after checking for heaping effects, and pooling the sighting distances into suitable intervals and truncating the farthest $5 \%$ of the observations on occasions (Buckland et al., 1993). Checking for size-bias in detection of animal clusters (Drummer \& McDonald, 1987) led to a nonsignificant regression equation at $\alpha=0.10$ for all species; and hence the mean cluster size was used for analysis. Variances in encounter rates of animals between transect were estimated empirically (Buckland et al., 1993).

\section{Reconstructing the diet of tigers}

Undigested remains in tiger scats $(n=109)$ were analysed to estimate the diet, as it is an efficient and 
widely used method (Schaller, 1967; Johnsingh, 1983; Karanth \& Sunquist, 1995; Biswas \& Sankar, 2002; Sankar \& Johnsingh, in press). Scats were collected whenever encountered along transects and forest trails within the ISA and distinguished from those of other predators by their shape and ancillary evidences such as scrapes and tracks. Unidentified scats were not included in analysis. The hair remains of prey were used for species identification following Mukherjee, Goyal \& Chellam $(1994 a, b)$ using reference samples at the laboratory of the Wildlife Institute of India, Dehradun, India. Since prey size was very variable, the frequency of occurrence (proportion of total scats in which an item was found) was assessed as well as the relative occurrence of prey items (number of times an item was found) by examining 20 hairs at random from each scat (Mukherjee et al., $1994 a, b)$ to circumvent the possible biases (Karanth \& Sunquist, 1995). To assess the influence of sample size on results, 10 scats were chosen randomly for analysis. This was continued until all scats had been included and the cumulative frequency of occurrence of different prey was used to infer the effect of sample size on the results (Biswas \& Sankar, 2002).

For estimating the relative contribution of prey species differing in their body size in the tigers' diet, a correction factor developed by Ackerman, Lindzey \& Hernker (1984) for the cougar Felis concolor, L. was used, and assuming that tigers have a similar digestive physiology to cougars. The equation is: $y=1.980+0.035 x$, where $y$ is the biomass of prey consumed $(\mathrm{kg})$ to produce a single field collectable scat and $x$ is the average body weight of the prey species $(\mathrm{kg})$. The body weights of the potential prey species were taken from literature (Prater, 1971; Eisenberg $\&$ Seidensticker, 1976; Karanth \& Sunquist, 1995).

\section{Estimating prey selection by tiger}

Comparison of observed counts of each prey item in the scat, with estimated prey availability was used to assess selectivity in predation. The expected number of scats having a particular prey species under non-selective predation was calculated following Karanth \& Sunquist (1995) as: $\pi_{j}=d_{j} \lambda_{j} / \Sigma d_{j} \lambda_{j}$; where prey species $j$ has a population density $d_{j}$, and $\lambda_{j}$ is the average number of field collectable scats produced by the tiger from an individual of species $j\left(\lambda_{j}=x / y\right.$; Ackerman et al., 1984). Karanth \& Sunquist (1995) reasoned that encountering prey groups rather than individuals determines the predation events by predators. So density of groups as well as of idividuals was used to estimate the expected proportions of prey species under non-selective predation. To estimate the expected contribution of individual prey items $\left(\pi_{j}\right.$, or prey availability), 1000 bootstrap iterations were performed using the program SCATMAN (Hines, 1999). Following this, prey selectivity was assessed by the multinominal likelihood ratio test (Link \& Karanth, 1994; Biswas \& Sankar, 2002) between observed and expected contributions by each prey item, with $\alpha=0.05$ level.
Table 1. Density (numbers $/ \mathrm{km}^{2}$ ) estimates of six wild prey species in the intensive study area (ISA) of Ranthambhore National Park, Rajasthan, during November 2000 to April 2001. $d_{g}$ and $d_{i}$, estimated density of groups and individuals, respectively; $\mathrm{CV}$, estimated coefficient of variance

\begin{tabular}{llrlrl}
\hline Species & $\begin{array}{l}\text { Sample size } \\
\text { (no. of groups) }\end{array}$ & \multicolumn{1}{c}{$\begin{array}{l}\text { CV } d_{g} \\
(\%)\end{array}$} & \multicolumn{1}{c}{$d_{i}$} & $\begin{array}{l}\text { CV } d_{i} \\
(\%)\end{array}$ \\
\hline Chital & 257 & 6.69 & 27.99 & 31.00 & 28.60 \\
Sambar & 196 & 4.57 & 25.53 & 17.15 & 12.16 \\
Nilgai & 196 & 4.11 & 27.28 & 11.36 & 27.92 \\
Chinkara & 52 & 2.35 & 30.93 & 5.62 & 31.97 \\
Wild pig & 40 & 1.35 & 23.26 & 9.77 & 26.24 \\
Common langur & 52 & 2.37 & 16.62 & 21.75 & 18.00 \\
Total & - & 21.44 & - & 96.65 & - \\
\hline
\end{tabular}

\section{RESULTS}

\section{Density of wild prey species}

The estimated densities of groups and of individuals of the six wild species are in Table 1 . In terms of density of groups, chital was the most abundant, followed by sambar, nilgai, common langur, chinkara and wild pig. In terms of density of individuals, chital was again the most abundant, followed by common langur, sambar, nilgai, wild pig and chinkara. On average, 21.44 groups of wild prey species containing 96.65 individuals were estimated to occur per $\mathrm{km}^{2}$. Of these groups, $22 \%$ were of small animals (chinkara and common langur, $<20 \mathrm{~kg}$ ); $37.5 \%$ were of medium-sized animals (chital and wild pig, 20 $50 \mathrm{~kg}$ ) and $40.5 \%$ were of large animals (sambar and nilgai, $50 \mathrm{~kg})($ Table 1$)$.

\section{Composition of tiger diet}

Eight prey species were identified in the 109 scats examined. Sixty-three scats $(58 \%)$ had a single prey item, 45 scats $(41 \%)$ had two prey items while only a single scat (1\%) had more than two prey species. $4.67 \%$ of hair remains could not be identified and these were not included in further analysis, whose results are presented in Table 2. The relative contribution of each species in the tigers' diet stabilized after $c .50$ scats were examined; so our sample size of 109 is deemed sufficient (Fig. 2).

Both approaches (frequency of occurrence and relative occurrence of prey items) gave similar results (Table 2). In general, wild species contributed to $c$. $88-89 \%$ of the tigers' diet, while domestic livestock contributed c. 10 $12 \%$. Chital and sambar together constituted the bulk (c. 78\%) of the tigers' diet, while the other wild species made lesser contributions (Table 2). We calculated the average biomass of prey individual consumed by tiger to be between 107 and $114 \mathrm{~kg}$, but this tends to overestimate prey-size as selectivity for age-sex category remains unaccounted. 
Table 2. Prey species composition in tiger Panthera tigris scats $(n=109)$ and their relative biomass contribution in tiger diet in Ranthambhore National Park, Rajasthan, between November 2000 and April 2001. Where $x$ and $y$ are related through the equation $y=$ $1.980=0.035 \times$ (Ackerman et al., 1984)

\begin{tabular}{|c|c|c|c|c|c|c|}
\hline Prey item & $\begin{array}{l}\text { Body } \\
\text { weight } \\
(\mathrm{kg}),(x)\end{array}$ & $\begin{array}{l}\text { Frequency of } \\
\text { occurrence } \\
\text { as } \%(F)\end{array}$ & $\begin{array}{l}\text { Relative } \\
\text { occurrence } \\
\text { as } \%(r)\end{array}$ & $\begin{array}{l}\text { No. of } \\
\text { collectable } \\
\text { scats per } \\
\text { kill }(y)\end{array}$ & $\begin{array}{l}\text { Biomass } \\
\text { consumed }^{\text {a }} \\
\left(F^{*} y \text { as \%) }\right.\end{array}$ & $\begin{array}{l}\text { Biomass } \\
\text { consumed } \\
\left(F^{*} r \text { as \%) }\right.\end{array}$ \\
\hline Chital & 45 & 61.47 & 45.67 & 12.66 & 30.31 & 31.04 \\
\hline Sambar & 125 & 50.46 & 36.86 & 20.13 & 46.77 & 47.25 \\
\hline Nilgai & 180 & 7.34 & 3.27 & 21.74 & 7.49 & 5.18 \\
\hline Chinkara & 12 & 1.83 & 0.58 & 5.00 & 0.31 & 0.26 \\
\hline Wild pig & 38 & 4.59 & 2.89 & 11.48 & 1.71 & 1.83 \\
\hline Buffalo & 273 & 6.42 & 2.60 & 23.67 & 8.94 & 5.73 \\
\hline Cattle & 180 & 2.75 & 2.89 & 21.74 & 2.14 & 4.57 \\
\hline $\begin{array}{l}\text { Common } \\
\text { Langur }\end{array}$ & 8 & 8.26 & 4.86 & 3.54 & 2.34 & 2.10 \\
\hline
\end{tabular}

${ }^{\text {a }}$ According to frequency of occurrence.

${ }^{\mathrm{b}}$ According to relative frequency of occurrence.
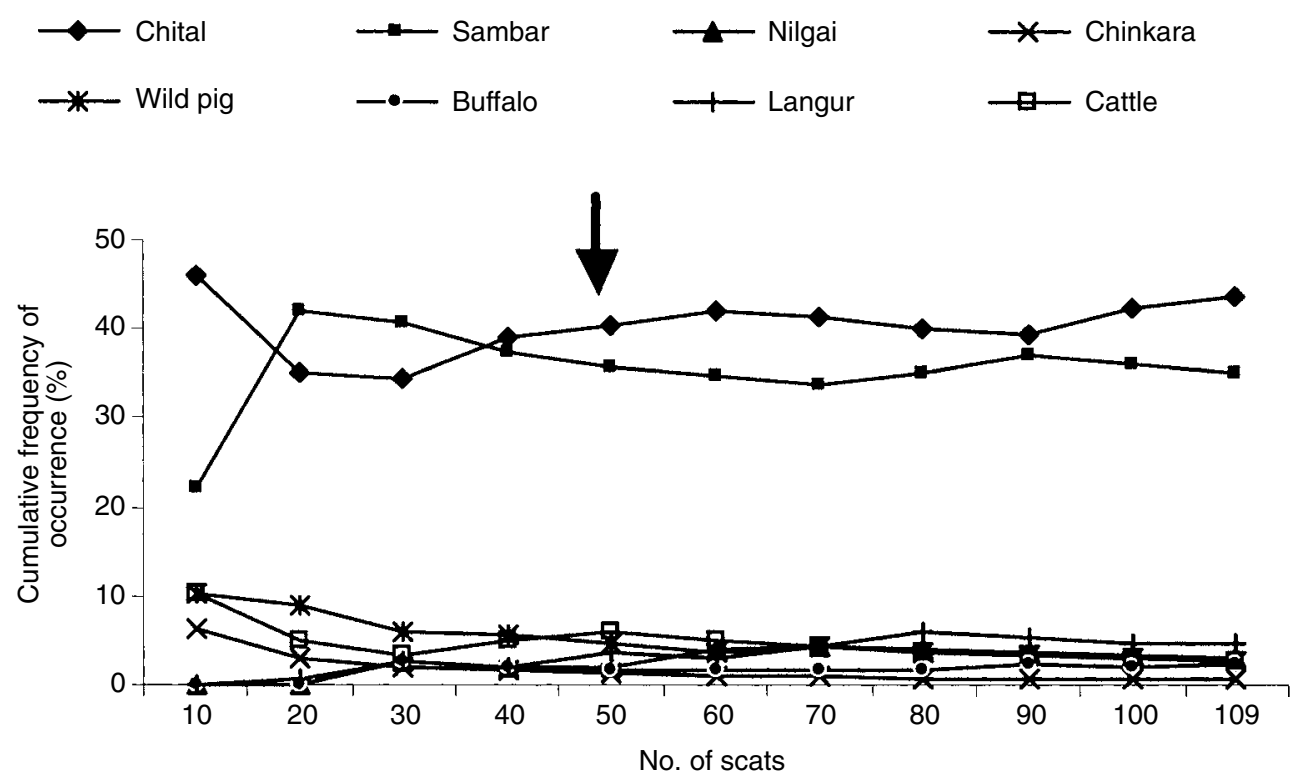

Fig. 2. Relationship between contributions of eight prey species in tiger Panthera tigris diet with number of scats examined from Ranthambhore National Park, Rajasthan, during November 2000 to April 2001.

\section{Prey selection}

Results of prey selectivity relate only to wild species that comprised 88 to $89 \%$ of the tigers' diet. The multinomial likelihood ratio test gave a significant result for overall prey selection based on availability of prey groups $\left(\chi^{2}=\right.$ 59.15, d.f. $=5, P<0.01)$ as well as of individuals $\left(\chi^{2}=\right.$ 38.17 , d.f. $=5, P<0.01)$. Subsequently, selectivity for each prey species was assessed.

In terms of group densities, chital $(P<0.01)$, sambar $(P<0.01)$ and common langur $(P<0.05)$ were preyed upon in excess of their availability, suggesting positive selection or preference. But nilgai $(P<0.01)$ and chinkara $(P=0.05)$ were preyed upon less than their availability, suggesting negative selection or underuse. Wild pig was preyed in proportion to its availability (no selection, $P>$ 0.05 ).
In terms of individual-densities; chital, sambar and wild pig were seen to be preferred (positive selection, $P<0.01$ for each), nilgai was not preferred (negative selection, $P<$ 0.01 ) with chinkara and langur being utilised in proportion to their availability (no selection, $P>0.05$ ).

\section{DISCUSSION}

\section{Prey availability and prey selection}

Our estimates of densities are similar to those of Kumar (2000). When compared to other areas having similar prey assemblage, our ISA had a very high density of large prey (sambar and nilgai; Table 3) possibly because of aggregation of animals into areas close to water. Moreover, $40.5 \%$ of the animal groups encountered on 
Table 3. Comparison of density of ungulates (animals $/ \mathrm{km}^{2}$ ) of five sites with the intensive study area (ISA) in Ranthambhore National Park

\begin{tabular}{|c|c|c|c|c|c|}
\hline & ISA & $\begin{array}{l}\text { Gir lion } \\
\text { sanctuary }^{\mathrm{a}}\end{array}$ & $\begin{array}{l}\text { Pench tiger } \\
\text { reserve }^{b}\end{array}$ & $\begin{array}{l}\text { Keoladeo } \\
\text { national } \\
\text { park }^{\mathrm{c}}\end{array}$ & $\begin{array}{l}\text { Kanha } \\
\text { sanctuary }\end{array}$ \\
\hline Chital & 31.00 & 25.2 & 80.7 & 9.79 & 49.7 \\
\hline Sambar & 17.15 & 1.8 & 6.09 & 0.75 & 1.5 \\
\hline Nilgai & 11.36 & 0.4 & 0.43 & 7.00 & - \\
\hline Chinkara & 5.62 & 1.2 & - & - & - \\
\hline Wild pig & 9.77 & 2.1 & 2.59 & 2.24 & 2.5 \\
\hline
\end{tabular}

Sources: ${ }^{\text {a }}$ Khan et al. (1996); ${ }^{\mathrm{b}}$ Biswas \& Sankar (2002); ${ }^{\mathrm{c}}$ Haque (1990); ${ }^{\mathrm{d}}$ Schaller (1967).

transects were of large-bodied animals, in comparison to only $7.25 \%$ reported from Nagarhole National Park (Karanth \& Sunquist, 1995; comprised of sambar, gaur Bos gaurus Smith, and elephant Elaphus maximus L.). High availability of large prey in the study area would be expected to influence prey selection by tigers, as they are usually known to have a predilection for larger prey (McDougal, 1977; Sunquist, 1981; Johnsingh, 1983; Karanth \& Sunquist, 1995; Stoen \& Wegge, 1996; Biswas \& Sankar, 2002).

Since the majority of scats had either a single (58\%) or just two prey $(41 \%)$ species, analysing the frequency of occurrence and relative occurrence of prey items gave similar results (Table 2). Multiple prey items are rare in scats of large predators such as tiger (Biswas \& Sankar, 2002) and lion Panthera leo L. (Mukherjee et al., 1994a), whereas they are common in smaller carnivores like canids (Reynolds \& Aebischer, 1991). As reported by several studies (McDougal, 1977; Sunquist, 1981; Johnsingh, 1983; Karanth \& Sunquist, 1995; Stoen \& Wegge, 1996; Biswas \& Sankar, 2002; Sankar \& Johnsingh, in press), the cervids (chital and sambar) formed the bulk (c. 78\%) of the tigers' diet. Like other studies (Karanth \& Sunquist, 1995; Biswas \& Sankar, 2002) our data do not account for selectivity in age-sex classes of a prey species; causing possible overestimation of prey size selection. Never the less, average weight of a prey individual consumed $(107-114 \mathrm{~kg})$ was higher than reported from Nagarhole (65.5 kg; Karanth \& Sunquist, 1995) and from Pench Tiger Reserve (82.1 kg; Biswas \& Sankar, 2002) and the influence of prey size availability seems to be reflected on the food habits of the tiger, as suggested by previous studies (McDougal, 1977; Sunquist, 1981; Johnsingh, 1983; Karanth \& Sunquist, 1995; Stoen \& Wegge, 1996; Biswas \& Sankar, 2002).

Our data do not cover all seasons, however, the calculation of $\pi_{j}$ accounted for a high variability in $d_{j}$ (Table 1) and $\lambda_{j}$ (Link \& Karanth, 1994).

\section{Conservation issues}

A high density of large prey in parts of Ranthambhore make the dry forests of western India a potential site for long-term conservation planning for tigers, because large ungulates can attain high densities even in successional and disturbed forests (Karanth \& Sunquist, 1992). But, despite this high abundance in Ranthambhore, domestic livestock accounted for $10-12 \%$ of the tigers' diet, and can pose challenges to the park management since large predators often get into serious conflict with humans over livestock depredation (e.g. Oli, Taylor \& Rogers, 1994; Saberwal et al., 1994; Mishra, 1997). Livestock grazing is a major problem in Ranthambhore (Berkmuller, Mukherjee \& Mishra, 1990), with > 3000 heads of livestock residing in the core area itself (Jain, 2001). Active management can lead to reducing the dependence of predators on livestock over time, and pronounced shifts in predator diets have been reported (e.g. Kitchener, 1991; Chellam, 1993) in response to enhanced wild prey availability. In fact, during the 16-year period between 1973 and 1989, frequency of livestock remains in scats of Asiatic lions of Gir, Gujarat, western India, dropped from $78.5 \%$ to $25.9 \%$ (Chellam, 1993). The current eco-development initiatives attempt to re-establish populations of wild prey by reducing people's dependence on parks (World Bank, 1996; MacKinnon et al., 1999; Jain, 2001). Active management inputs like village eco-development, fodder farming for livestock, and silvipastoral development (World Bank, 1996; MacKinnon et al., 1999; Jain, 2001) can reduce the human pressures on Ranthambhore and alleviate the potential for conflict posed by livestock depredation by tigers. Future studies on the food habits of tigers in Ranthambhore, when compared with our data would show whether conservation inputs helped in reducing the tigers' dependence on livestock over time. This is extremely important for conservation of the last remnant populations of tigers in semi-arid, dry deciduous habitats of western India and emphasizes the importance of generating information on the diet of tigers from different parts of its range.

\section{Acknowledgements}

We thank Ministry of Environment \& Forests, Government of India, and Tiger Watch, Sawai Madhopur, for funding the study. The Wildlife Institute of India, Dehradun, and Centre for Ecological Research and Conservation, Mysore, are thanked for their support. Rajasthan Forest Department and Ranthambhore Tiger Project, Sawai Madhopur, are thanked for their kind cooperation. We are grateful to M. E. Sunquist, University of Florida-Gainesville, and E. L. Fitzhugh, University of California, Davis, and two anonymous referees for their comments on previous drafts. Our field assistants are thanked for their valuable contribution to the study.

\section{REFERENCES}

Ackerman, B. B., Lindzey, F. G. \& Hernker, T. P. (1984). Cougar food habits in southern Utah. J. Wildl. Manage. 48: 147-155. 
Anderson, D. R., Burnham, K. P., Lubow, B. C., Thomas, L., Stephen Corn, P., Medica, P. A. \& Marlow, R. W. (2001). Field trials of line transect methods applied to estimation of desert tortoise abundance. J. Wildl. Manage. 65: 583-597.

Berkmuller, K., Mukherjee, S. K. \& Mishra, B. K. (1990). Grazing and cutting pressures on Ranthambhore National Park, Rajasthan, India. Environ. Conserv. 17: 135-140.

Biswas, S. \& Sankar, K. (2002). Prey abundance and food habit of tigers (Panthera tigris tigris) in Pench National Park, Madhya Pradesh, India. J. Zool. (Lond.) 256: 411-420.

Buckland, S. T., Anderson, D. R., Burnham, K. P. \& Laake, J. D. (1993). Distance sampling: estimating abundances of biological populations. London: Chapman \& Hall.

Burnham, K. P., Anderson, D. R. \& Laake, J. D. (1980). Estimation of density from line transect sampling of biological populations. Wildl. Monogy. 72: 1-202.

Champion, F. W. \& Seth, S. K. (1968). A revised survey of the forest types of India. Nasik, India: Government of India Press.

Chellam, R. (1993). Ecology of the Asiatic lion (Panthera leo persica). $\mathrm{PhD}$ dissertation, Saurashtra University, India.

Drummer, T. D. \& McDonald, L. L. (1987). Size bias in line transect sampling. Biometrics 43: 13-21.

Eisenberg, J. F. \& Seidensticker, J. (1976). Ungulates in southern Asia: a consideration of biomass estimates for selected habitats. Biol. Conserv. 10: 293-308.

Haque, M. N. (1990). Study on the ecology of wild ungulates of Keoladeo National Park, Bharatpur, Rajasthan. PhD dissertation, Aligarh Muslim University, India.

Hines, J. E. (1999). SCATMAN-software to test the hypothesis of prey selectivity based on random samples of predator scats. USGS-PWRC. www.mbr.nbs.gov:80/scatman.html

Jain, P. (2001). Project tiger status report, Project Tiger, MoEF. New Delhi, India: Government of India.

Johnsingh, A. J. T. (1983). Large mammalian prey-predators in Bandipur. J. Bombay nat. Hist. Soc. 80: 1-57.

Karanth, K. U. \& Stith, B. M. (1999). Prey depletion as a critical determinant of tiger population viability. In Riding the tiger: tiger conservation in human dominated landscapes: 100-113. Siedensticker, J., Christie, S. \& Jackson, P. (Eds). Cambridge: Cambridge University Press.

Karanth, K. U. \& Sunquist, M. E. (1992). Population structure, density and biomass of large herbivores in the tropical forests of Nagarhole, India. J. trop. Ecol. 8: 21-35.

Karanth, K. U. \& Sunquist, M. E. (1995). Prey selection by tiger, leopard and dhole in tropical forests. J. Anim. Ecol. 64: 439-450.

Kellert, S. R., Black, M., Rush, C. R. \& Bath, A. J. (1996). Human culture and large carnivore conservation in North America. Conserv. Biol. 10: 977-990.

Khan, J. A., Chellam, R., Rodgers, W. A. \& Johnsingh, A. J. T. (1996). Ungulate densities and biomass in tropical dry deciduous forests of Gir, Gujarat, India. J. trop. Ecol. 12: 149-162.

Kitchener, A. (1991). The natural history of the wild cats. London: Christopher Helm, A. \& C. Black.

Kumar, N. S. (2000). Ungulate density and biomass in the tropical semi-arid forest of Ranthambore, India. MSc thesis, Pondicherry University, India.

Laake, J. L., Buckland, S. T., Anderson, D. R. \& Burnham, K. P. (1998). DISTANCE user's guide. Fort Collins, CO: Colorado State University.

Link, W. A. \& Karanth, K. U. (1994). Correcting for overdispersion in tests of prey selectivity. Ecology 75: 2456-2459.
MacKinnon, K., Mishra, H. \& Mott, J. (1999). Reconciling the needs of conservation and local communities: global environment facility support for tiger conservation in India. In Riding the tiger: tiger conservation in human dominated landscapes: 307-315. Siedensticker, J., Christie, S. \& Jackson, P. (Eds). Cambridge: Cambridge University Press.

McDougal, C. (1977). The face of the tiger. London: Rivington.

Mishra, C. (1997). Livestock depredation by large carnivores in the Indian Trans-Himalaya: conflict in perceptions and conservation prospects. Environ. Conserv. 24: 338-343.

Mukherjee, S., Goyal, S. P. \& Chellam, R. (1994a). Refined techniques for the analysis of Asiatic lion Panthera leo persica scats. Acta Theriol. 39: 425-430.

Mukherjee, S., Goyal, S. P. \& Chellam, R. (1994b). Standardization of scat analysis techniques for leopard (Panthera pardus) in Gir National Park, western India. Mammalia 58: 139-143.

Oli, M. K., Taylor, I. R. \& Rogers, M. E. (1994). Snow leopard Panthera uncia predation of livestock: an assessment of local perceptions in the Annapurna conservation area, Nepal. Biol. Conserv. 68: 63-68.

Prater, S. H. (1971). The book of Indian animals. 3rd edn. Bombay: Bombay Natural History Society.

Reynolds, J. C. \& Aebischer, N. J. (1991). Comparison and quantification of carnivore diet by faecal analysis: a critique, with recommendations, based on a study of the fox Vulpes vulpes. Mammal Rev. 21: 97-122.

Saberwal, V. K., Gibbs, J. P., Chellam, R. \& Johnsingh, A. J. T. (1994). Lion-human conflict in Gir forest, India. Conserv. Biol. 8: 501-507.

Sankar, K. \& Johnsingh, A. J. T. (In press). Food habits of tiger (Panthera tigris) and leopard (Panthera pardus) in Sariska Tiger Reserve, Rajasthan, India, as shown by scat analysis. Mammalia.

Schaller, G. B. (1967). The deer and the tiger: a study of wildlife in India. Chicago, IL: University of Chicago Press.

Sharma, S. (1983). A contribution to the botany of Ranthambhore Tiger Reserve. New Delhi, India: Government of India.

Stoen, O. \& Wegge, P. (1996). Prey selection and prey removal by tiger (Panthera tigris) during the dry season in lowland Nepal. Mammalia 60: 363-373.

Sunquist, M. E. (1981). The social organization of tigers (Panthera tigris) in Royal Chitwan National Park. Smithson. Contrib. Zool. 339: $1-98$.

Sunquist, M. E. \& Sunquist, F. (1989). Ecological constraints on predation by large fields. In Carnivore behaviour, ecology and evoluation: 282-301. Gittleman, J. L. (Ed.). Ithaca, NY: Cornell University Press.

Sunquist, M. E., Karanth, K. U. \& Sunquist, F. (1999). Ecology, behaviour and resilience of the tiger and its conservation needs. In Riding the tiger: tiger conservation in human dominated landscapes: 5-18. Siedensticker, J., Christie, S. \& Jackson, P. (Eds). Cambridge: Cambridge University Press.

Varman, K. S. \& Sukumar, R. (1995). The line transect method for estimating densities of large mammals in a tropical deciduous forest: an evaluation of models and field experiments. J. Bioscience. 20: 273-287.

Weber, W. \& Rabinowitz, A. (1996). A global perspective on large carnivore conservation. Conserv. Biol. 10: 1046-1054.

World Bank (1996). Staff appraisal report: India eco-development project. Report no. 14914-IN, South Asia Dept. II, Agricultural and Water division. Delhi: World Bank. 